\title{
Land Subsidence in Cam Son Region of Vietnam and the Solutions to Minimize Its Negative Impacts to Construction Works
}

\author{
Phi Hong Thinh ${ }^{1, *}$, Nguyen Thi $\mathrm{Nu}^{2}$, Phi Truong Thanh ${ }^{3}$ \\ ${ }^{1}$ Civil Engineering Faculty, University of Transport and Communications, Hanoi, Vietnam, thinhph@utc.edu.vn \\ ('corresponding author) \\ ${ }^{2}$ Department of Engineering Geology, University of Mining and Geology, Hanoi, Vietnam, nguyenthinu@ @umg.edu.vn \\ ${ }^{3}$ Geological Faculty, Hanoi University of Natural Resources and Environment, Hanoi, Vietnam, thanhgislab@ gmail.com
}

\begin{abstract}
Land subsidence has been taking place in Cam Son ward, Cam Pha city, Quang Ninh province, not only causing damage to the construction works, economic damages but also causing confusion for the local people. Therefore, studying the land subsidence and proposing solutions to minimize its negative impacts to construction works in Cam Son region are necessary and urgent, in order to reduce economic losses, stabilize the spirit of the local people. The main causes of the land subsidence are due to the existence of Karst underground space, the systems of northwestsoutheast and northeast-southwest faults, the existence of easily eroded soil layers which lie on the original rock, the fluctuation of groundwater level and static load from the filling soils and construction works. The most obvious mechanism of the land subsidence is the sinkhole. The study results have divided the study region into three areas with low, moderate and high risk of the land subsidence. A number of structural and non-structural solutions have been proposed to serve construction management and planning.
\end{abstract}

Key words: Cam Son region, Fault, Karst, Land subsidence, Limestone, Sinkhole.

\section{INTRODUCTION}

Cam Son is a ward of Cam Pha city, Quang Ninh province, Vietnam (see Figure 1). Cam Son ward has an area of 10.84 $\mathrm{km}^{2}$; the population is 35,280 people; and the population density is 3,073 people $/ \mathrm{km}^{2}$ in 2019 .

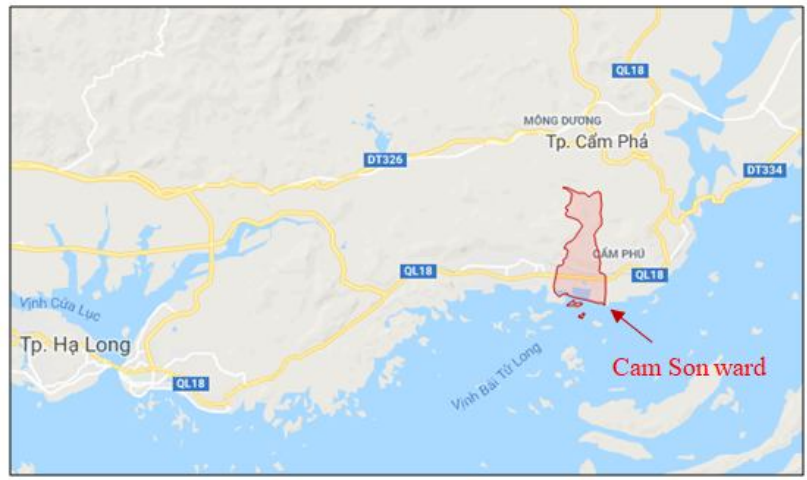

Figure 1: Geographical location of Cam Son ward, Cam Phacity,QuangNinhprovince, Vietnam

Recently, in Cam Pha city, the land subsidence has been happening on a large area of Cam Tay, Cam Dong, Cam Son and Cam Phu wards. In particular, in Cam Son, the land subsidence occurred with a dense frequency and large scale, causing a number of construction and transport works in the region damaged, not only causing economic damages but also causing confusion for the local people. Here, the land subsidence has been occurring in densely populated areas such as Tay Nam Da Mai, Thuy Son, Nam Son, Quang Hong, Cam Son 1, and Cao Son areas, making a number of civil and industrial constructions cracks and falls (see Figure 2). Many households had to demolish houses or lost the cost of repairing houses and filling holes. Some collapse holes occurred on highway No.18 endangering road users, increasing the cost of filling and repairing the road surface. Therefore, studying the land subsidence and proposing solutions to minimize its negative impacts on construction and transport works in Cam Son region are necessary and urgent, in order to reduce economic losses, stabilize the spirit of the local people.

The land subsidence has been interested in researching in Vietnam and other countries and achieved remarkable results, gradually contributing to mitigation of damages and reasonable planning proposals. Most notably, studies on land subsidence hazard of the authors such as Trinh M.T. and DelwynG.F(2000) [10], Do M.D. et al. (2012) [4],Tran Q.C et al. (2014) [9], Nguyen V.B. (2015) [5], Phi H.T. and 
Strokova L.A. (2013, 2015) [7], [8], Aleksey V.K. et al. (2019) [1], AymenAwad, Firas Al Bajari and Feras Al Adday (2019) [3], and AymenAwad (2020) [2]. In these researchs, the causes of land subsidence were determined by two groups: natural factors and human factors. Specifically, geological - lithological, geomorphological - tectonic and hydrogeological - engineering geological factors are considered as the "need" condition, the factors which change the natural dynamics of groundwater and impacts on the surface are "sufficient" conditions.
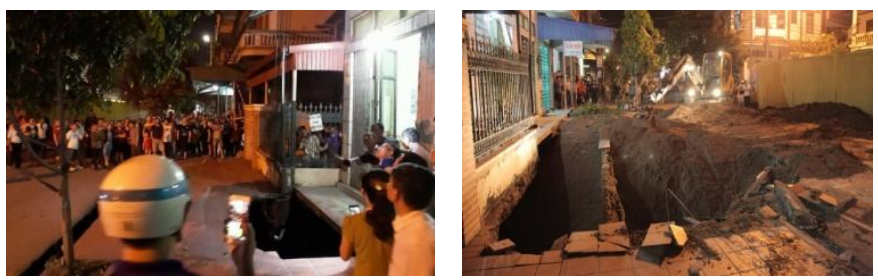

Figure 2:Some land subsidence sites in Cam Son in 2018

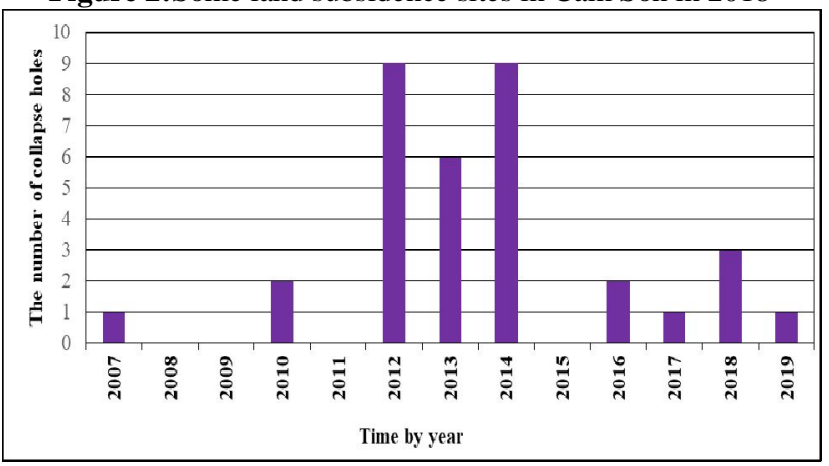

Figure 3: Statistical graph of number of collapse holes by year in Cam Sonward (prepared by Phi H.T. in 2020)

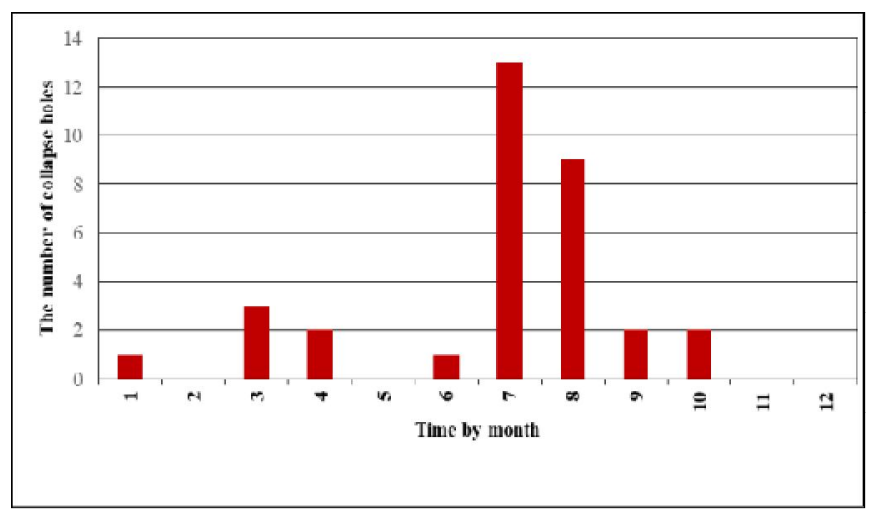

Figure 4: Statistical graph of number of collapse holes by month in Cam Son ward (prepared by Phi H.T. in 2020)

The land subsidence in Cam Son is recorded to have occurred scattered for a long time from 2007 to 2010, broke out from 2012 to 2014 and lasting until now. The number of collapse holes appeared in the region also increased significantly over time, peaking from 6 to 9 collapse holes appeared in the years 2012 - 2014. Most of the collapse holes appeared from March to October annual, in which July and August are the time when the most collapse holes appear (see Figure 3 and Figure 4).

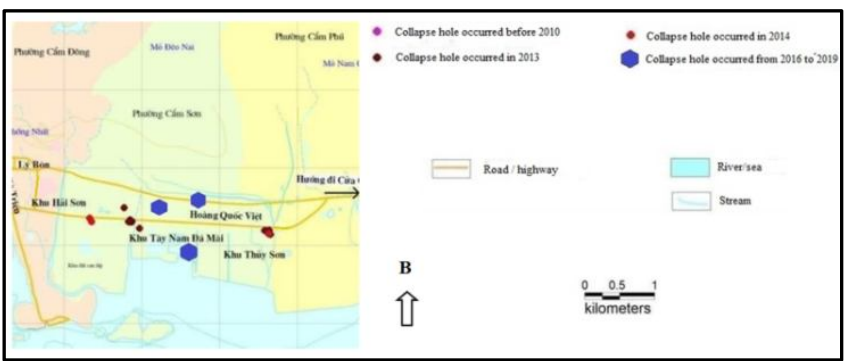

Figure 5: Sketch of the land subsidence sites in Cam Son(prepared by Tran Q.C. in 2014 [9] and supplementedby Phi H.T. in 2020)

The collapse holes have the following characteristics:

- Distribute on a large scale but tend to distribute in clusters, at the intersection between tectonic fault systems (see Figure $5)$;

- Occur on Quaternary unconsolidated sedimentary formations;

- Occur on many types of terrain and different types of geomorphology;

- Occur in the areas covered by limestone;

- Immediately happen in a short time;

- Have quite circular shape and dimesions of $1-3 \mathrm{~m}$ in wide $\mathrm{x}$ $1-4 \mathrm{~m}$ in length and $1-3 \mathrm{~m}$ in depth;

- There is no phenomenon of dehydration in holes when soil collapse occurs.

\section{MATERIAL AND METHODOLOGY}

\subsection{Topography and geomorphology}

The topography of Cam Son is mainly mountainous including $55.4 \%$ of the hilly and mountainous area, $16.29 \%$ of the midland, $15.01 \%$ of the plain and $13.3 \%$ of the coastal area. On the basis of age and origin, the geomorphology of Cam Son is divided into 6 types: Synthetic erosion slope; The terrain of aluvial - proluvialsediments (apQ $\mathrm{IV})$; Aluvialcones; $2^{\text {nd }}$ marine shelf $\left(\mathrm{mQ}_{\mathrm{IV}}\right) ; 1^{\text {st }}$ marine shelf $\left(\mathrm{mQ}_{\mathrm{IV}}\right)$; The terrain of marine - swampy sediments (bmQ $\left.\mathrm{bV}\right)$. They are composed by alluvial, proluvial and marine swampy sediments [9].

\subsection{Geological structure and physic-mechanical properties of the strata}

According to the Vietnam Geological and Minerals Map, Ha Long (Hon Gai) F-48-XXXSheet with scale of 1:200,000, published by the Vietnam Geology and Minerals Department in 1999 [5], in Cam Son region, most of the collapse holes are distributed in the Quaternary sediments and below is the limestone of the Bac Son Formation (C-Pbs). This rock is exposed around the study region (see Figure 6). 


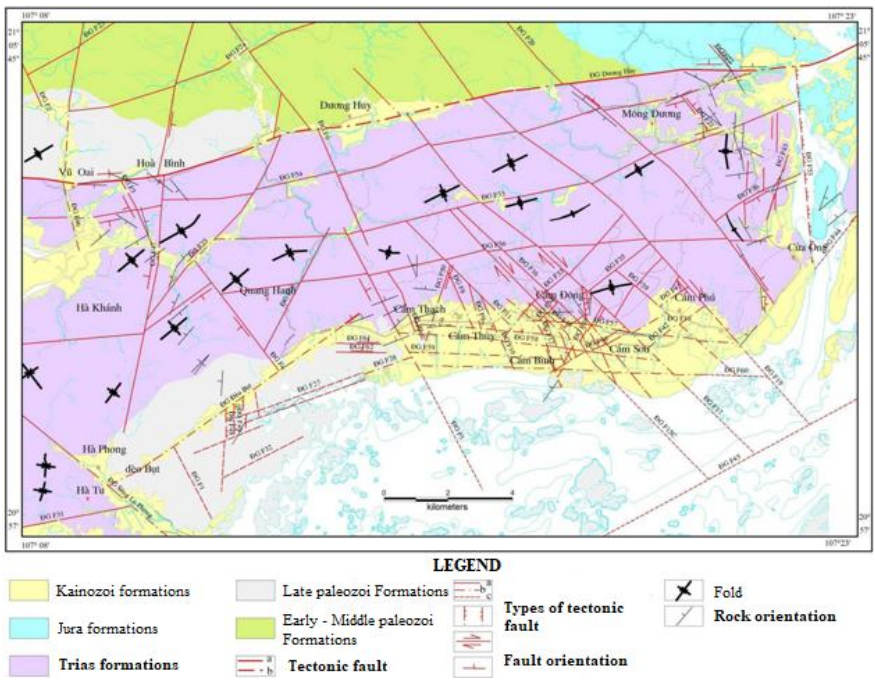

Figure 6: Sketch of Cam Pha geological structure with scale of 1: 200,000(prepared by Nguyen C.L. in 1999 [6])

Limestone in the region is broken by latitudinal, longitudinal, northeast-southwest and northwest-southeast fault systems. The faults in the region generally slope from $60^{\circ}$ to $90^{\circ}$. In which, the latitudinal faults in the south of the region has the sloping surface to the north; in the northern area, they have a slightly sloping surface to the south [6]. As a result, the Cam Son region has strongly developed the broken zones.

\subsection{The general stratigraphy}

Itincludes the following soil and rock layers (see Figure 7 and Table 1):

- Layer 1: Filling soil (A mixture of boulders, cobbles, construction wastes, gravel and sand, somewhere mixed with coal dust). The thickness varies from 3.0 to $5.5 \mathrm{~m}$;

- Layer 2: Medium dense, dark grey, yellowish grey Sand with gravel and seashell $\left(\mathrm{mQ}_{\mathrm{IV}}{ }^{1-2}\right)$. The thickness varies from 1.5 to $5.5 \mathrm{~m}$;

- Layer 3: Medium dense, dark grey, yellowish grey clayey Sand with gravel and seashell $\left(\mathrm{mQ}_{\mathrm{IV}}{ }^{1-2}\right)$ with the thickness of about 3.0m;

- Layer 4: Firm, yellowish grey, reddish brown, yellowish brown sandy Clay with gravel $\left(\mathrm{mQ}_{\mathrm{III}}\right)$. The thickness varies from 2.0 to $14.0 \mathrm{~m}$;

- Layer 5: Light grey, slightly weathered, strongly fractured Limestone. In the layer, there are many Karst underground caves with different sizes and depths. Karst underground caves are usually located at the level of -10 to $-28 \mathrm{~m}$ and have height of 3 to $8 \mathrm{~m}$. The caves are often filled with yellowish grey sandy clay Mud with gravel originating from the soil layers above. The distance from the ceiling of caves to the limestone surface is 1.0 to $3.5 \mathrm{~m}$;

- Layer 6: Yellowish grey sandy clay Mud with gravel. They cram in Karst underground caves $(\mathrm{H})$.

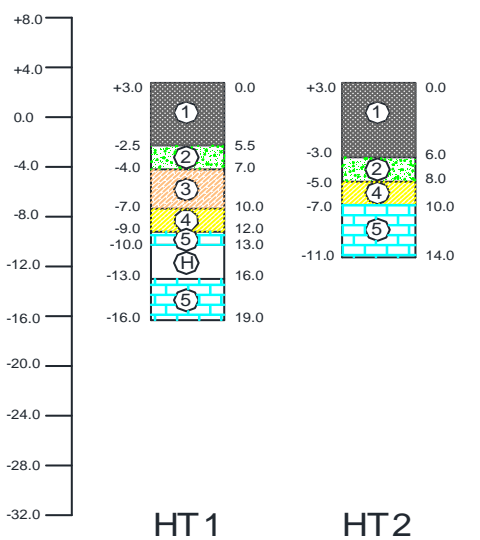

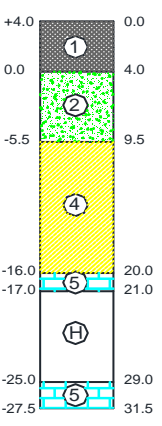

HT3

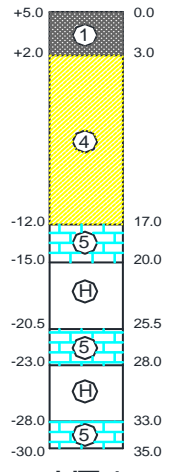

HT 4
Figure 7:. Typical borehole logs (prepared by Phi H.T. in 2020)

Table 1: Some main physico-mechanical propertiesof the strata

\begin{tabular}{|c|c|c|c|c|c|c|c|}
\hline $\begin{array}{c}\text { Proper- } \\
\text { ties }\end{array}$ & Unit & L 1 & L 2 & L 3 & L 4 & L 5 & L 6 \\
\hline $\begin{array}{l}\text { Natural } \\
\text { moisture } \\
\text { content }\end{array}$ & $\%$ & $\mathrm{C}_{\mathrm{a}}$ & mSsgn & 18.0 & 18.7 & - & 54.6 \\
\hline $\begin{array}{l}\text { Natural } \\
\text { unit } \\
\text { weight }\end{array}$ & $\mathrm{g} / \mathrm{cm}^{3}$ & 1.70 & 1.96 & 1.91 & 1.95 & 2.74 & 1.67 \\
\hline $\begin{array}{l}\text { Specific } \\
\text { gravity }\end{array}$ & $\mathrm{g} / \mathrm{cm}^{3}$ & 2.67 & 2.67 & 2.71 & 2.70 & - & 2.69 \\
\hline $\begin{array}{l}\text { Void } \\
\text { ratio }\end{array}$ & - & - & 0.712 & 0.673 & 0.646 & - & 1.491 \\
\hline $\begin{array}{l}\text { Internal } \\
\text { friction } \\
\text { angle } \\
\end{array}$ & $\begin{array}{l}\text { Deg- } \\
\text { ree }\end{array}$ & $38^{0} 00^{\prime}$ & $36^{0} 00^{\prime}$ & $22^{0} 54^{\prime}$ & $15^{0} 26^{\prime}$ & - & $8^{0} 38^{\prime}$ \\
\hline $\begin{array}{l}\text { Cohe- } \\
\text { sion }\end{array}$ & $\begin{array}{c}\mathrm{kG} / \mathrm{c} \\
\mathrm{m}^{2}\end{array}$ & - & - & 0.062 & 0.184 & - & 0.046 \\
\hline $\begin{array}{l}\text { Coeffi- } \\
\text { cient of } \\
\text { compre- } \\
\text { ssion }\end{array}$ & $\mathrm{cm}^{2} / \mathrm{k}$ & 0.025 & 0.028 & 0.025 & 0.026 & - & 0.061 \\
\hline $\begin{array}{l}\text { Sat. } \\
\text { uniaxial } \\
\text { compre- } \\
\text { ssion } \\
\text { strength }\end{array}$ & $\begin{array}{c}\mathrm{kG} / \mathrm{c} \\
\mathrm{m}^{2}\end{array}$ & - & - & - & - & 500 & - \\
\hline $\begin{array}{l}\text { Rock } \\
\text { quality } \\
\text { designa- } \\
\text { tion }\end{array}$ & $\%$ & - & - & - & - & $\begin{array}{c}35- \\
50\end{array}$ & - \\
\hline
\end{tabular}

Note: L 1 - Layer No.1

\subsection{Hydrological and hydrogeological characteristics}

In the study region, there is a surface flow north-south system (Hoa Chat river). The riverbed is from 30 to $35 \mathrm{~m}$ wide in the dry season; In the rainy season, it is $100 \mathrm{~m}$. The depth of river water varies from 2.5 to $5.0 \mathrm{~m}$. Based on the water storage conditions and lithological characteristics, the study region is divided into two aquifers as follows [9]:

- Pore-phreatic aquifer in Quaternary (Q) sediments: thickness is from $1 \mathrm{~m}$ in the eluvial deposites to $10 \mathrm{~m}$ in the aluvial sediments. The composition is mainly sandy Clay, clayey Sand with gravel and organic matter. The aquifer has 
Phi Hong Thinh et al., International Journal of Emerging Trends in Engineering Research, 8(4), April 2020, 1011 - 1018

a wide distribution area and covers all study region. Water can be used for drinking and living. The main source of the pore-phreatic aquifer is rainwater. Flow rate and permeability of the aquifer is quite small.

- Karst aquifer of Bac Son Formation (C-Pbs): It has static water level ranging from 3.7 to $34.0 \mathrm{~m}$, high flow rate and permeability.

\subsection{Methodolody}

Causes, mechanism and zoning of the land subsidence risk in Cam Sonare implemented according to methods: field survey, data collection, systematization, mapping of geological structure- tectonic activity, engineering geology hydrogeology - geophysics combination, geomorphological analysis, numerical modeling (finite element method by Plaxis software) and system analysis.

\section{RESULTS AND DISCUSSION}

\subsection{Causes of the land subsidence in Cam Son region}

- Geological structureand tectonic activity

The geological structure and tectonic activitiy cause the destruction, cracks in limestone and create broken zones; change the surface of the terrain; facilitate water storage. Water movement and temperature and humidity changing make the process of dissolving limestone more actively in broken rock, creating favorable conditions for the formation of Karst caves, hollows, grooves. Thus, it can be said that geological structure and tectonic activity are indirect cause, creating favorable conditions for the development of the land subsidence.

The northwest-southeast fault system has been shown to be modern and relevant in position with the majority of the land subsidence sites in Cam Son in recent years. In addition, when placing location of the land subsidence sites on the geological map, it was found that most of the land subsidence sites in the region concentrated mainly in the distribution of marine, alluvial - proluvial sediments aged early - middle Holocene with a relatively thin thickness (see Figure 8).

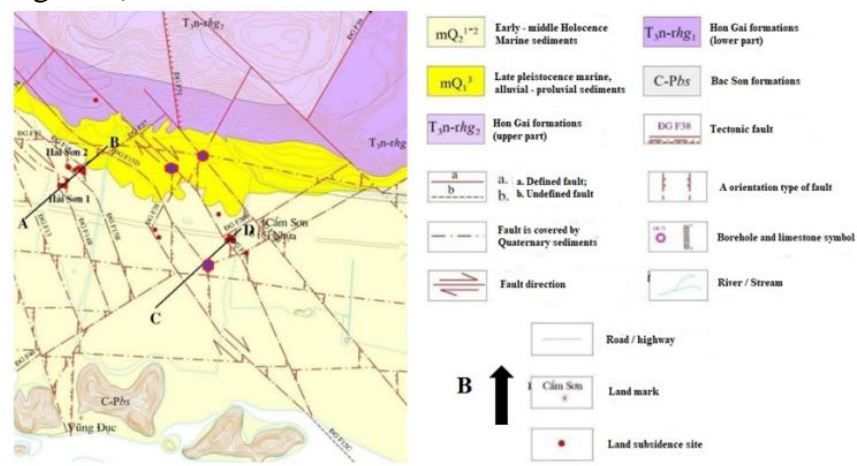

Figure 8: Sketch of geological structure through the location of the land subsidence sites in Cam Son (prepared by Tran Q.C.in 2014 [9], supplemented by Phi H.T. in 2020)
- Existence of Karst underground caves and shallow surface of limestone

The borehole logs (see Figure 7) show the Karst underground caves have different sizes and depths. They usually locate at the level of -10 to $-28 \mathrm{~m}$, and have the height of 3 to $8 \mathrm{~m}$. The caves are often filled with yellowish grey sandy clay Mud with gravel (layer 6)derived from soil layers laying above that were washed down. The distance from the ceiling caves to the limestone surface is from 1.0 to $3.5 \mathrm{~m}$. It can be found that location of the land subsidence sites distributed quite coinciding with the areas where limestone terrain tends to rise highly.

\section{- Change of coastline}

The coastline in the study region, during the period from 1969 up to now, has been largely "reversed sea" due to coastal dumping and landfilling. At the present, the coastline is the boundary of the coastal dumping site or landfilling area. Most of the land subsidence sites located close to the coastline and tend to be close to the alluvial cones. The change from coastal to continental environment has affected geological structure, creating favorable conditions for the development of the land subsidence in the study region (see Figure 9).
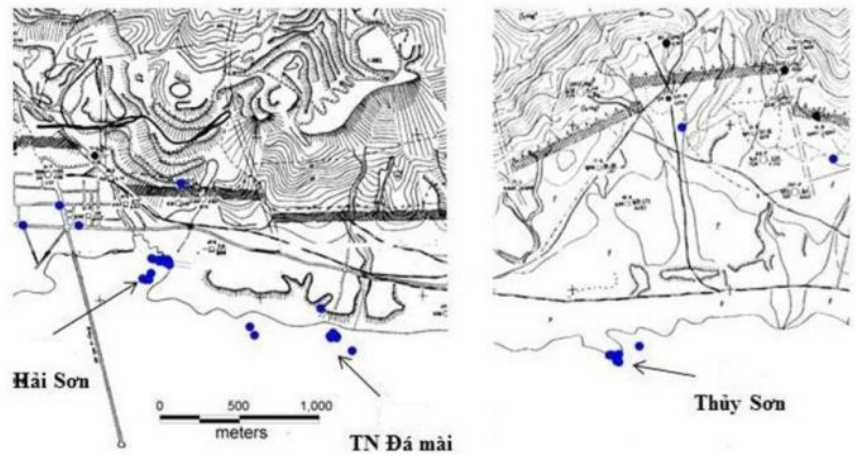

Figure 9:Location of the land subsidence sites and coastline before 1966(prepared by Trinh Van Due in 1967)

- Hydrographic and hydrogeological characteristics

- $\quad$ Surface flow

In the study region, Hoa Chat river runs under the north south direction, from DeoNai - CocSau coal mines to the sea. Currently, the river is embanked and prevented by concrete dams, becoming a drainage ditch for the region and the discharge of coal mines. The land subsidence sites occured near this surface flow system.

\section{- Groundwater characteristics}

There are two aquifers in the study region: a pore-phreatic aquifer in Quaternary unconsolidated sedimentsand a Karst aquifer in Bac Son carbonate sediments. In addition, there is a zone of mixed water betwwenpore-phreatic - Karst aquifersand Karst aquifer - seawater). The groundwater in 
the region moves from north to south and northwest to southeast directions. The land subsidence in the region occurred in the exposed areas of the pore-phreatic and Karst aquifers. The complicated hydrogeological conditions of the two aquifers, especially the presence of mixed water zone in the region indicated the relationship between the land subsidence and hydrogeological conditions here.

\section{- Underground water fluctuations}

Groundwater moves vertically and horizontally. In which, vertical movement with amplitude of 24 to $58 \mathrm{~cm}$; Horizontal movement is influenced by tide by month and by day.

Analysis of groundwater fluctuations in correlation with rainfall and tide at the time of the land collapse in Thuy Son (3 o'clock in July 29, 2014) shows that one day before the land collapse, the groundwater level at the monitoring stations decreased sharply from 24 to $31 \mathrm{~cm}$, and rainfall reached $77 \mathrm{~mm} /$ day, coinciding with the largest tidal amplitude in July. From that, it can be concluded that the fluctuations of vertical groundwater and especially horizontal groundwater play an important role in causing the land subsidence in Cam Son.

- Stratigraphy and physico-mechanical properties of the strata

Most of the study region is covered by marine Quaternary sediments. Below is the Carbon - Permian aged limestone of Bac Son formation (see Figure 8). The study of the current state of the land subsidence shows that holes occured only in areas where the surface is covered by saturated filling soil and non-cohesive soil.This characteristic is found in almost the land subsidence sites. The existence of these soils during the development of Cam Phacity has led to the formation of shallow aquifers, which have an impact on the development of the collapse holes.

Partial or complete loss of sandy Clay with gravel (layer No. 4) in holes was recorded in Thuy Son. Here, the stratigraphy is similar as the HT1 borehole (see Figure 7). In the broken limstone, the Karst cave was discovered with a height of $3 \mathrm{~m}$. There are soil layers No.1 to No.4 lying above limestone. The cave was filled with sandy clay Mud (soil layer No.6). This data adds evidence that the soil is easily attracted to the Karst underground space is soil layer No. 4.

\section{- Meteorological - oceanographic factor}

According to statistical data, the study region has an average annual rainfall of about $2,300 \mathrm{~mm}$ and is divided into two seasons: rainy season and dry season. The rainy season is concentrated from May to October with rainfall accounting for $85 \%$ of the total annual rainfall; the dry season with very small rainfall accounting for $15 \%$ of the total annual rainfall lasts from November to April every year.

Besides, the groundwater in the region is affected by the tide by day and by month. The influence of tide repeats by day, by month and by season has affected the fluctuation of groundwater.

Especially at the time of the land subsidence happened in July 2014, rainfall reached $77 \mathrm{~mm} /$ day (in July 28, 2014), and groundwater decreased from 24 to $31 \mathrm{~cm}$, and it was the time of the lowest and the highest tides in July 2014. Correlation of groundwater movement - meteorological condition (rainfall) - oceanographic condition (tide) reflects the role of natural factors such as meteorology - oceanography hydrogeology in the land subsidence hazard in the study region.

\section{- Periodic floods in the rainy season}

Running along the east-west, cutting through most of the land filled after 1990 is highway 18 (H18). Due to the embankment of H18, the areas along both sides of the highway have elevations of 1.0 to $1.5 \mathrm{~m}$ lower than $\mathrm{H} 18$. This road acts as a "natural barrier" limiting the flow from north to south (toward the sea). In Trung Son area, there still exist many ponds. The groundwater level in the filling soil layer is quite high. This is also an ability to stimulate land subsidence in the area. This problem has no evidence or experiment data, but it can completely affect the land subsidence in the study region.

- Increase the load from construction works

Currently, in Cam Son ward, civil and industrial constructions are from 1 to 5 floors, mainly using 2 types of foundation: strip foundation and raft foundation (see Figure10). The results of analyzing effect of the construction load to the land subsidence in the region were performed by Plaxis 8.2 software corresponding to two types of foundation: strip foundation and raft foundation with the scale of 1 to 5 floors; groundwater level changes from 4.0 to $34.0 \mathrm{~m}$ below the surface; stratigraphy of HT1 and HT4.

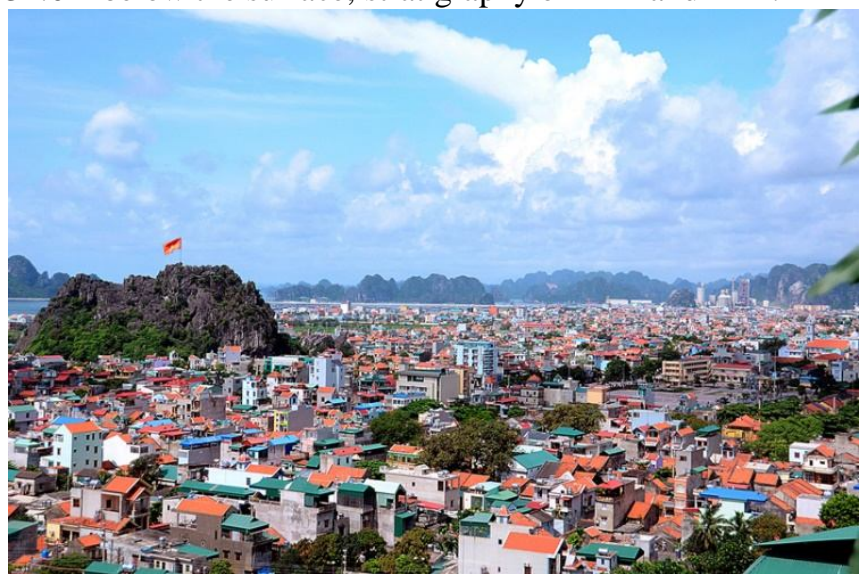

Figure 10: Current situation of civil and industrial constructions in Cam Son ward

\section{- Construction load}

The load due to civil and industrial constructions on the ground in the study region is calculated and listed in Table 2 below. 
Phi Hong Thinh et al., International Journal of Emerging Trends in Engineering Research, 8(4), April 2020, 1011 - 1018

Table 2: Pressure on the ground corresponding to types of foundation and construction scale

\begin{tabular}{|c|c|c|c|c|c|c|}
\hline \multirow{2}{*}{$\begin{array}{c}\text { Foun- } \\
\text { dation } \\
\text { type }\end{array}$} & \begin{tabular}{c} 
Pressure on the ground, $\mathbf{p}\left(\mathbf{t} / \mathbf{m}^{2}\right)$ \\
(m) \\
\cline { 2 - 7 }
\end{tabular} & $\begin{array}{c}\mathbf{1} \\
\text { floor }\end{array}$ & $\begin{array}{c}\mathbf{2} \\
\text { floors }\end{array}$ & $\begin{array}{c}\mathbf{3} \\
\text { floors }\end{array}$ & $\begin{array}{c}\mathbf{4} \\
\text { floors }\end{array}$ & $\begin{array}{c}\mathbf{5} \\
\text { floors }\end{array}$ \\
\hline \multirow{2}{*}{ Raft } & $20.0 \times 10.0$ & 1.5 & 3.0 & 4.5 & 6.0 & 7.5 \\
\hline \multirow{2}{*}{ Strip } & $\begin{array}{c}\text { Width of } \\
1.5 \mathrm{~m}\end{array}$ & 5.0 & 10.0 & 15.0 & 20.0 & 30.0 \\
\cline { 2 - 7 } & $\begin{array}{c}\text { Width of } \\
1.8 \mathrm{~m}\end{array}$ & 4.5 & 9.0 & 13.5 & 18.0 & 25.0 \\
\hline
\end{tabular}

- Evaluation method

The phenomenon of land subsidence is modeled; vertical displacement due to the increase of load from civil and industrial construction works calculated by finite element method using Plaxis software 8.2; Mohr - Coulomb material model was selected for the soil.

- $\quad$ Input parameters for the model

The input parameters for the model are shown in Table 3.

Table 3: Parameters for Hardening Soil model

\begin{tabular}{|l|c|c|c|c|c|c|}
\hline Parameter & $\begin{array}{c}\text { Sym- } \\
\text { bol/Un } \\
\text { it }\end{array}$ & L1 & L 2 & L 3 & L 4 & L 5 \\
\hline $\begin{array}{l}\text { Material } \\
\text { model }\end{array}$ & \multicolumn{5}{|c|}{ Mohr - Couloumb } \\
\hline $\begin{array}{l}\text { Material } \\
\text { type }\end{array}$ & - & $\begin{array}{c}\text { Drain } \\
\text {-ed }\end{array}$ & $\begin{array}{c}\text { Drain } \\
\text {-ed }\end{array}$ & $\begin{array}{c}\text { Drain } \\
\text {-ed }\end{array}$ & $\begin{array}{c}\text { Und- } \\
\text { raine } \\
\mathrm{d}\end{array}$ & $\begin{array}{c}\text { Drain } \\
\text {-ed }\end{array}$ \\
\hline $\begin{array}{l}\text { Natural bulk } \\
\text { density }\end{array}$ & $\begin{array}{c}\gamma, \\
\mathrm{kN} / \mathrm{m}^{3}\end{array}$ & 17.0 & 19.6 & 19.1 & 19.5 & 27.0 \\
\hline $\begin{array}{l}\text { Saturated } \\
\text { bulk density }\end{array}$ & $\begin{array}{c}\gamma_{\mathrm{sat}}, \\
\mathrm{kN} / \mathrm{m}^{3}\end{array}$ & 17.3 & 19.7 & 20.2 & 20.3 & 27.3 \\
\hline $\begin{array}{l}\text { Elastic } \\
\text { modulus }\end{array}$ & $\begin{array}{c}\mathrm{E}, \\
10^{3} \mathrm{kN} / \\
\mathrm{m}^{2}\end{array}$ & 7.0 & 18.0 & 5.1 & 3.9 & 71.2 \\
\hline $\begin{array}{l}\text { Poisson' } \\
\text { ratio }\end{array}$ & $\begin{array}{c}\mathrm{v} \\
\mathrm{f}\end{array}$ & 0.30 & 0.30 & 0.30 & 0.35 & 0.25 \\
\hline $\begin{array}{l}\text { Cohesion } \\
\mathrm{kN} / \mathrm{m}^{2}\end{array}$ & $\begin{array}{c}\varphi, \\
\text { Degree } \\
\text { friction } \\
\text { angle }\end{array}$ & 38.0 & 36.0 & 23.0 & 15.5 & - \\
\hline
\end{tabular}

\section{- $\quad$ Model steps}

Step 1: Model the problem into Plaxis software;

Step 2: Grid the 15 nodes triangle element;
Step 3: Declare underground water level and bulk density of layers;

Step 4: Declare the construction process;

Step 5: Export the calculation results.

- $\quad$ Results of running the model with Plaxis software 8.2

The results of running the model by Plaxis 8.2 software determined the vertical displacement of the ground below the foundation of civil and industrial constructions, considering:

+ Application to 2 types of foundation: strip and raft foundation;

+ Scale of constructions: 1 to 5 floors;

+ Groundwater depth:4.0 to 34.0m from the ground surface;

+ Stratigraphy: HT1 and HT4 borehole logs (shown in Figure 7).

Realizing that deformation caused by civil and industrial constructions in the study region is quite small, ranging from 39.36 to $287.62 \mathrm{~mm}$. There was no phenomenon of Karst collapse (see Figure 11 and Figure 12).
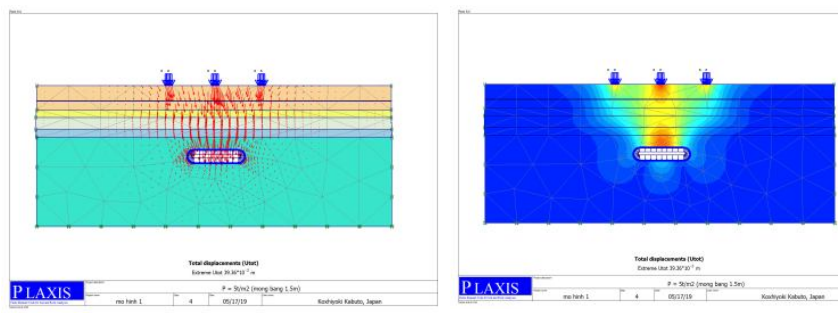

Figure 11: Vertical displacement corresponding to the strip foundation with 3 rows spaced $8 \mathrm{~m}$ apart, $1.5 \mathrm{~m}$ wide and the scale of 1 -storey civil and industrial construction, corresponding to groundwater level of 4.0m from the ground; borehole log HT1

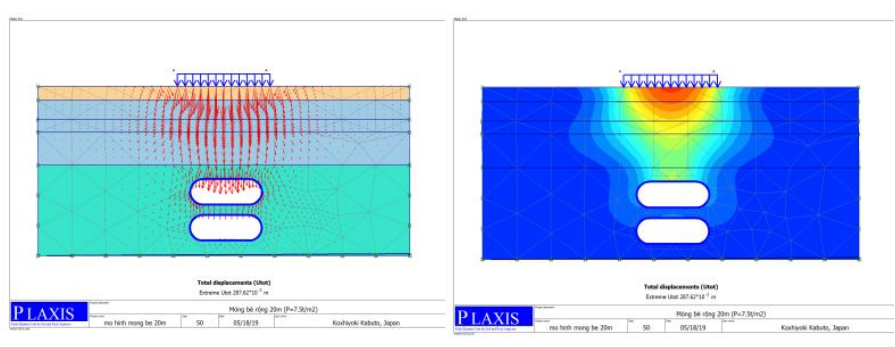

Figure 12: Vertical displacement corresponding to raft foundation with dimension of $20 \mathrm{~m} \times 10 \mathrm{~m}$ and scale of 1-storey civil and industrial construction, corresponding to groundwater level of $34.0 \mathrm{~m}$ from the ground; borehole $\log$ HT4

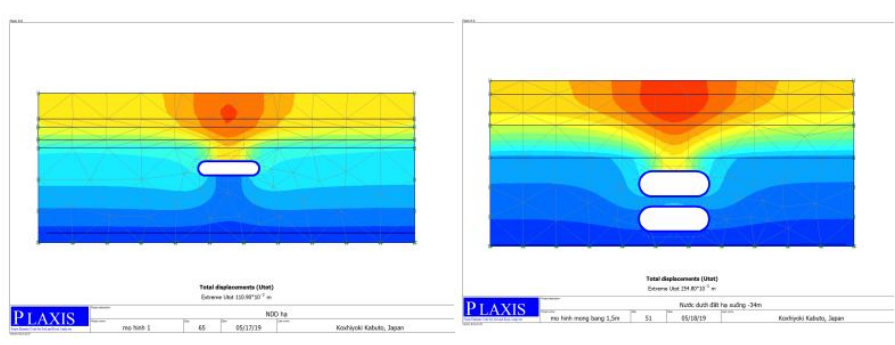

Figure 13: Vertical displacement in the non-construction area when groundwater level drops from 4.0 to $34.0 \mathrm{~m}$; borehole logs HT1 and HT4 
Phi Hong Thinh et al., International Journal of Emerging Trends in Engineering Research, 8(4), April 2020, 1011 - 1018

The land subsidence in the non-construction area due to groundwater dropping from 4.0 to $34.0 \mathrm{~m}$ is also small, ranging from 110.90 to $254.80 \mathrm{~mm}$. There is no collapse of Karst cave (see Figure 13).

\subsection{Mechanism}

The non-homogeneous materialsare led through Karstic underground cave throat and fractured zone of limestone, so the land subsidence can develop right on the Karst underground caves or not directly above them. This mechanism is called "sinkhole" (see Figure 14).

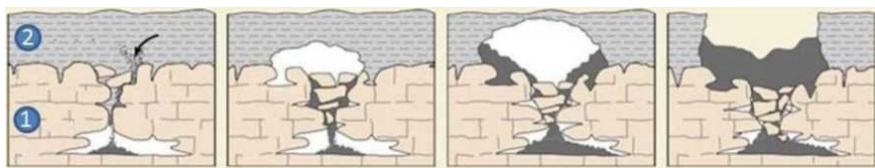

Note: 1 - limestone; 2 - critical soil layer covering the surface of underground limestone

Figure 14: Illustration of mechanism for forming the land subsidence in Cam Son

\subsection{Prediction zoning of the land subsidence risk in Cam Son}

Prediction zoning sketch of the land subsidence risk in Cam Son was established based on geological structureand tectonic activity, characteristics of limestone surface, characteristics of covering strata, and broken zone at the surface of the underground limestone. The favorable areas for the land subsidence in Cam Son are:

- The areas of broken limestone of Bac Son Formation, at the intersection between latitudinal, longitudinal, northeastsouthwest and northwest-southeast fault systems.

- Where the cover strata are thin; the groundwater fluctuates strongly and is directly influenced by tide.

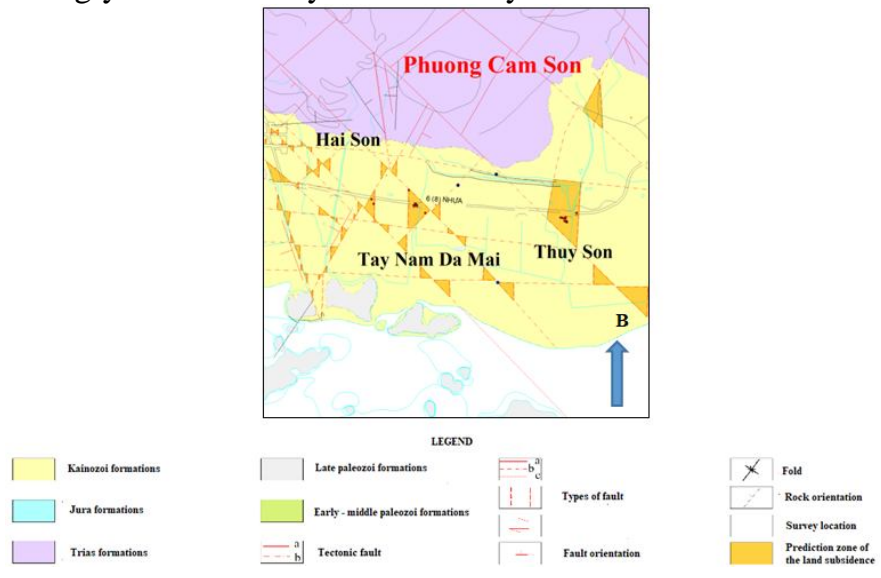

Figure 15:Prediction zoning sketch of the land subsidence risk in Cam Son

Based on the favorable geological structures for the land subsidence above, it is allowed to establish a prediction zoning sketch of the land subsidence risk in Cam Son (see Figure 15).
On this sketch, the areas created by the intersection between latitudinal, longitudinal, northeast-southwest and northwestsoutheast fault systems (dark yellow areas) are predicted as areas with high risk of the land subsidence. The limestone areas of Bac Son Formation (C-Pbs) covered by Quaternary sediments (yellowish area) are assessed as areas with moderate risk. The remaining areas (grey areas) are assessed as areas with low risk of the land subsidence.

\subsection{Discussion}

To remedy, minimize and prevent the land subsidence, the following structural and non-structural solutions can be applied.

- Foundation solution

For high-rise buildings with large loads, pile foundation should be used; and strictly follow the procedures for pile construction in the region of Karst underground caves.

For low-rise buildings, reinforced concrete strip or raft foundation should be used. Raft foundation should be used for buildings with larger load.

The use of these solutions to increase the hardness of the foundation, withstand the appearance of sinkholes under the foundation, ensure the stable working of the above structures.

The material for backfilling excavation should be compacted clayey soil to avoid accumulation of rainwater and surface water.

- Structural solutions

Buildings should have reinforced concrete beam and frame structure to ensure the hardness of the constructions.

- Non-structural solutions

- Management and urban planning

Regions with many Karst underground caves should be planned as greenery and flower gardens. The other areas may be arranged constructions. It is necessary to strictly prohibit the operation of coal collection in Hoa Chat river bed.

- Education and propaganda

Conducting education and propaganda among the people so that people can properly understand the land subsidence hazard, how to identify and minimize damage.

- Scientific research and monitoring

In addition to expanding the study region, the impact of the stimulating factors Should be studied more carefully. 


\section{CONSLUSION}

- Current status of the land subsidence and hole's characteristics in the study region: The holes occurred suddenly, immediately in a short time. Before the land subsidence, there were no signs or clear warning signs. The holes distributed in a concentrated manner, did not have clear rules but tend to be concentrated in areas with flat terrain and a short distance to the sea or very close to the alluvial cones. They tend to distribute from west-northwest to east-southeast direction.

- Causes and mechanism of the land subsidence: The existence of Karst underground space, the most important of which is the first Karst underground caves below the limestone surface. These Karst underground caves tend to concentrate at the intersection between fault systems in the region, especially at the intersection between the northwestsoutheast fault system and the northeast-southwest fault system. The critical layer in the cover strata is soft to firm, yellowish grey, reddish brown, yellowish brown sandy Clay with gravel (the layer No.4). The layer with nonhomogeneous composition is easily attracted, washed away into Karst underground space through broken zones of limestone. Fluctuations of groundwater level and static load from filling soil and constructions are one of the important stimulating causes.

- The most obvious mechanism of the land subsidence is the "sinkhole".

- Zoning of the land subsidence risk: Prediction zoning sketch of the land subsidence risk in Cam Son was established based on 04 factors such as geological structure and tectonic activity, characteristics of limestone surface, characteristics of covering strata, and broken zone on surface of the underground limestone.The study results have identified three areas with low, moderate and high risk of the land subsidence.

- To remedy, minimize and prevent the land subsidence risk, structural and non-structural solutions such as pile foundation, reinforced concrete beam and frame structure, management and urban planning, education and propaganda, scientific research and monitoring should be applied.

\section{REFERENCES}

1. Aleksey Vladimirovich Kirjukhin et al. Efficiency of Schemes of Active Broadband Damping of Vibration Forces Transmitted by Vibration Insulation to the Foundation, International Journal of Emerging Trends in Engineering Research, Vol. 7, No.12, pp. 733-738, December 2019. https://doi.org/10.30534/ijeter/2019/017122019

2. Aymen Awad. Guidelines for Civil Structures Demolition Method Selection to Enhance Environmental Protection, International Journal of Emerging Trends in Engineering Research, Vol. 8, No.2, pp. 307-313, February 2020. https://doi.org/10.30534/ijeter/2020/11822020

3. Aymen Awad, Firas Al Bajari and Feras Al Adday. A Case Study on Rainwater Harvesting and Reuse in Jordan, International Journal of Emerging Trends in Engineering Research, Vol. 7, No.11, pp. 398-402, November 2019.

https://doi.org/10.30534/ijeter/2019/017112019

4. Do Minh Duc. et al.Study on Mechanism of Forming Sinkholes in the Kart Underground Areas: Case Study in Cho Don Area of Bac Kan Province (Nghiên cứu cơ chế hình thành các hố sụt ở khu vực phân bố Karst ngầm (Lấy ví dụ khu vực Chợ Đồn, tỉnh Bắc Kạn)),Journal of Science and Technology of Mining and Geology,No. 38/4-2012, pp. 16-24, April 2012 (in Vietnamese).

Availableonline:

http://tapchi.humg.edu.vn/public/uploads/files/4._Nguye n_Minh_Duc(accessed on 15February 2020).

5. Nguyen Van Binh.Study on Characteristics of Quaternary Sediments and Environment Related to Land Subsidence in the Western Area of Hanoi (Nghiên cứu đặc điểm trầm tích đệ tứ và mối liên quan với hiện tượng lún mặt đất ở khu vực phía tây thành phố Hà Nội), Ph.D. dissertation, Vietnam Academy of Science and Technology, Hanoi, Vietnam, 2015 (in Vietnamese).

Availableonline:

http://gust.vast.vn/images/trang/Luan\%20an_Nguyen\%2 0Van\%20Binh.pdf(accessed on 15December 2019).

6. Nguyen Cong Luong.Geological and MineralsResources Map of Vietnam on 1:200,000, Ha Long (Hon Gai) F-48-XXXSheet, Department of Geology and Minerals of Vietnam, Hanoi, Vietnam, 1999 (in Vietnamese).

7. Phi Hong Thinh and Strokova Ludmila Aleksandrovna. Prediction of Land Subsidence Caused by Groundwater Exploitation in Hanoi, Vietnam, Using Multifactorial Correlation Analysis, Journal of Sciences in Cold and Arid Regions, Vol. 5, No.5, pp.644-653, January 2013.

DOI: 10.3724/SP.J.1226.2013.00644

8. Phi Hong Thinh and Strokova Ludmila Aleksandrovna. Prediction Maps of Land Subsidence Caused by Groundwater Exploitation in Hanoi, Vietnam,Journal of Resource-Efficient Technologies,Vol. 1, pp.80-89, December 2015. https://doi.org/10.1016/j.reffit.2015.09.001

9. Tran Quoc Cuong et al.Research to Identify Causes and Propose Solutions to Reduce Land Subsidence in Cam Pha City (Nghiên cứu xác định nguyên nhân và đề xuất giải pháp giảm thiểu sụt lún đất trên địa bàn thành phố Cẩm Phả),Report on scientific research topic, code 105-ĐXPS.01-2014,Institute of Geological Sciences of Vietnam, Hanoi, Vietnam, 2014 (in Vietnamese).

10. Trinh Minh Thu and Delwyn G. Fredlund. Modelling Subsidence in the Hanoi City Area, Vietnam, Canadian Geotechnical Journal,Vol. 37, No.3, pp. 621637, June 2000.

DOI:10.1139/cgj-37-3-621 